\title{
Spontaneous Occurrence of the Sekiguchi Lesion on Rice cv. Himenomochi*
}

\author{
Jun ISOTA**, Yoshiyuki KADOWAKI** and Sakae ARASE***,
}

Key words : Sekiguchi lesion, mutant rice, Bipolaris oryzae.

Sekiguchi and Furuta $^{3)}$, in 1965, reported a unique lesion type in a mutant rice plant (cv. Sekiguchi-asahi) of rice cv. Asahi. The lesions were visible as water soaked gray spots in its early stage, and then enlarged rapidly, gradually merged and finally occupied the entire plant. At this stage, the lesions became orange to orange brown in color. This unique lesion was induced by infection with Bipolaris oryzae or Magnaporthe grisea (= Pyricularia oryzae) or by treatment with chemical agents and was named Sekiguchi lesion by Kiyosawa ${ }^{2)}$.

In 1991, one mutant rice seedling was found from cv. Himenomochi in a paddy field of Shimane Agricultural Experiment Station. This mutant formed orange to orange brown lesions on its leaves (Plate I-A). This unique lesion was same as the Sekiguchi lesion reported previously in color and size of lesions. In this paper, we report the mutant from rice cv. Himenomochi has the same character as cv. Sekiguchi-asahi has. Brief reports of this study have been published previously ${ }^{1}$.

The seeds from a mutant of rice cv. Himenomochi which had been harvested in 1991 were planted and grown in a greenhouse as reported previously ${ }^{1}$. When rice $c v$. Sekiguchi-asahi was grown in the greenhouse or the paddy field, many Sekiguchi lesions were certainly formed on the leaves of each plant by the heading stage. So, whether each seed from a mutant of cv. Himenomo-

Table 1. Formation of the Sekiguchi lesion (SL) by rice seedlings from seeds harvested from a mutant rice plant

\begin{tabular}{ccc}
\hline \hline $\begin{array}{c}\text { Total no. of rice } \\
\text { seeds used }\end{array}$ & $\begin{array}{c}\text { No. of rice plants } \\
\text { formed SL } \\
\text { (Line A) }\end{array}$ & $\begin{array}{c}\text { No. of rice plants } \\
\text { did not from SL } \\
\text { (Line B) }\end{array}$ \\
\hline 170 & $162(95.3 \%)$ & $8(4.7 \%)$ \\
\hline
\end{tabular}

Rice seeds were harvested from a mutant in the paddy field in 1991. They were planted and were grown in the greenhouse in 1992. The naturally-formed SLs on each plant were observed after the heading stage to determine whether each plant has the Sekiguchi character or not. chi has the Sekiguchi character or not was also determined by observing naturally-formed Sekiguchi lesions on each plant after the heading stage.

When 170 rice seeds from a mutant forming Sekiguchi lesions were planted and grown in the greenhouse, the plants (line A) from 162 seeds formed Sekiguchi lesions $(95.3 \%)$ and the other ones (line B) from 8 seeds did not (4.7\%) (Table 1). When rice seeds from above two lines were harvested and planted, there was a large difference in percentage of Sekiguchi lesion forming plants between lines A and B. Percentage of the Sekiguchi lesion forming plants from lines $\mathrm{A}$ and $\mathrm{B}$ was 99.4 and $23.0 \%$, respectively. Further, the rice plants from line B seeds showed the segregation ratio agreeing with 3 normal without Sekiguchi lesion : 1 mutant with Sekiguchi lesion (Table 2).

We named this mutant cv. Sekiguchi-himenomochi and rice seeds from seedlings of lines A or B with Sekiguchi lesions were used as cv. Sekiguchi-himenomochi. Rice cv. Sekiguchi-himenomochi was crossed with cvs. Aichi-asahi, Asahi, Himenomochi, K1, Sekiguchi-asahi and Toride 1 to determine the inheritance of the Sekiguchi character. When the reactions of $F_{1}$ plants from crosses between the Sekiguchi mutants (cvs.

Table 2. Formation of the Sekiguchi lesion (SL) by rice plants from seeds harvested from lines A and B shown in Table 1

\begin{tabular}{cccc}
\hline $\begin{array}{c}\text { Rice seeds } \\
\text { from : }\end{array}$ & $\begin{array}{c}\text { Total number } \\
\text { of plants } \\
\text { investigated }\end{array}$ & $\begin{array}{c}\text { Number of } \\
\text { plants } \\
\text { formed SL }\end{array}$ & $\begin{array}{c}\text { Number of } \\
\text { plants did not } \\
\text { form SL }\end{array}$ \\
\hline $\begin{array}{c}\text { Line A } \\
\text { Line B }\end{array}$ & 155 & 154 & 1 \\
\hline $\begin{array}{c}\text { cv. Himeno- } \\
\text { mochi }\end{array}$ & 155 & 95 & 318 \\
\hline
\end{tabular}

Each rice seedling was grown in the greenhouse. The naturally-formed SLs on each plant were observed after the heading stage to determine whether each plant has the Sekiguchi character or not.

* This study was supported in part by a Grant-in-Aid for Research No. 07660058 to S. Arase from the Ministry of Education, Science and Culture of Japan

** Shimane Agricultural Experiment Station, Izumo 693, Japan＼cjkstart島根県農業試験場

*** Faculty of Life and Environmental Science, Shimane University, Matsue 690, Japan

$\dagger$ To whom correspondence should be addressed. 


\section{Plate I}
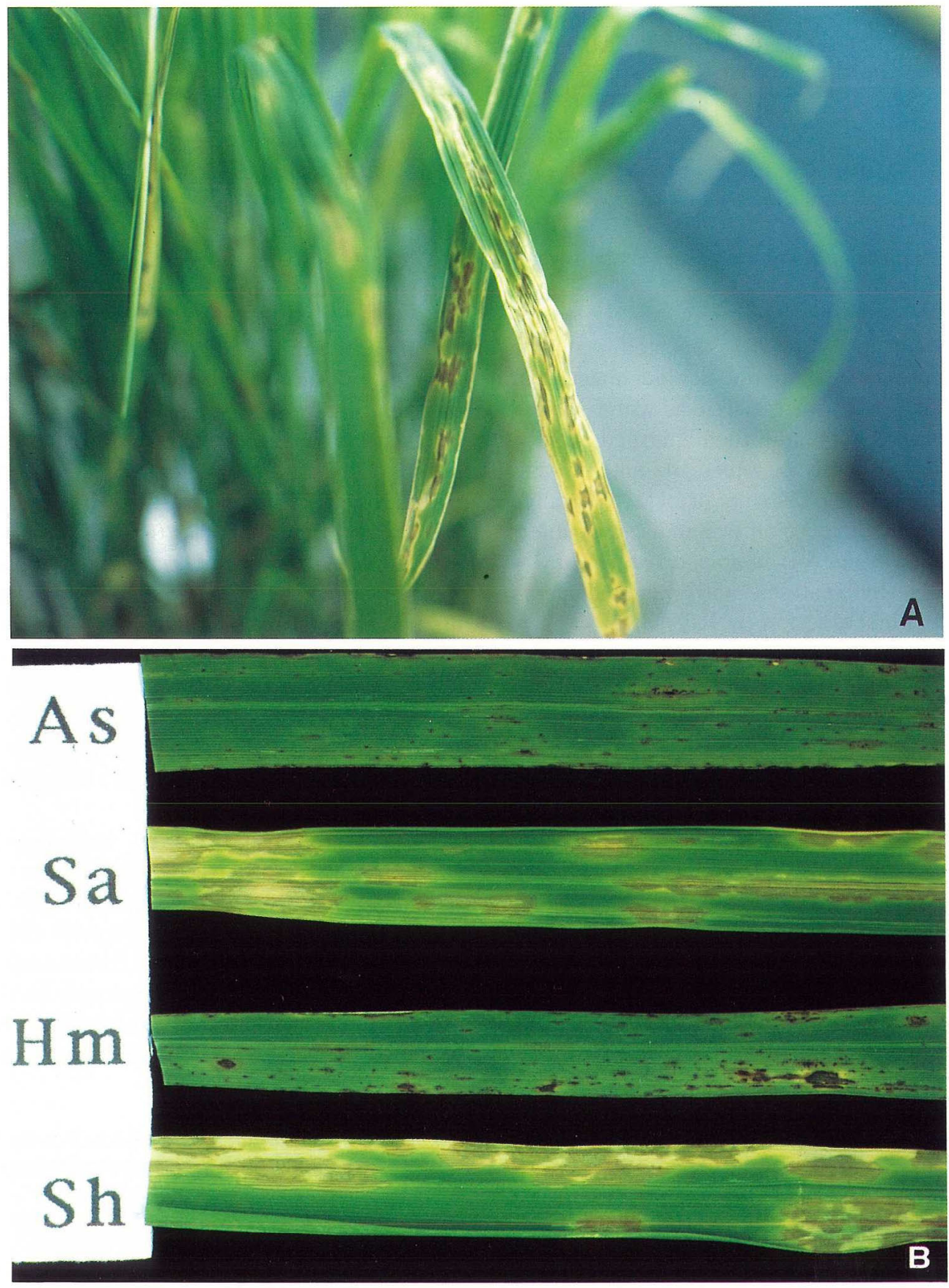

Plate I

A. Sekiguchi lesions spontaneously occurred on rice cv. Himenomochi.

B. Comparison of lesion on rice leaves of four cultivars formed by B. oryzae.

As, cv. Asahi; Sa, cv. Sekiguchi-asahi; Hm, cv. Himenomochi; Sh, cv. Sekiguchi-himenomochi. 
Table 3. The Sekiguchi lesion (SL)-forming ability of $F_{1}$ plants from crosses between cv. Sekiguchihimenomochi and several rice cultivars

\begin{tabular}{|c|c|c|c|c|}
\hline $\begin{array}{c}\text { Experiment } \\
\text { no. }\end{array}$ & $\begin{array}{c}\text { Cross } \\
\left(\text { 우 } \times 0^{7}\right)\end{array}$ & $\begin{array}{l}\text { Total no. of } \\
\text { rice seeds } \\
\text { checked }\end{array}$ & $\begin{array}{l}\text { Nature of } \\
\text { rice seeds }\end{array}$ & $\begin{array}{l}\text { Number of } \\
\text { plants } \\
\text { formed SL }\end{array}$ \\
\hline \multirow{4}{*}{ I } & $\mathrm{Sh}^{\mathrm{a})} \times \mathrm{Sa}^{\mathrm{b})}$ & 10 & $\mathrm{NG}^{\mathrm{e})}$ & 10 \\
\hline & $\mathrm{Sh} \times \mathrm{Aa}^{\mathrm{c})}$ & 4 & NG & 0 \\
\hline & $\mathrm{Sh} \times \mathrm{Hm}^{\mathrm{d})}$ & 8 & $G^{f)}$ & 0 \\
\hline & $\mathrm{Hm} \times \mathrm{Sh}$ & 2 & G & 0 \\
\hline \multirow{7}{*}{ II } & $\mathrm{Sh} \times \mathrm{Sa}$ & 9 & NG & 9 \\
\hline & $\mathrm{Sh} \times \mathrm{Aa}$ & 6 & NG & 0 \\
\hline & $\mathrm{Sh} \times \mathrm{Hm}$ & 27 & G & 0 \\
\hline & $\mathrm{Hm} \times \mathrm{Sh}$ & 5 & G & 0 \\
\hline & Sh $\times$ Asahi & 4 & NG & 0 \\
\hline & Sh $\times$ Toride 1 & 1 & NG & 0 \\
\hline & $\mathrm{Sh} \times \mathrm{K} 1$ & 5 & NG & 0 \\
\hline
\end{tabular}

Experiment I and II were carried out in 1992 and 1993, respectively. The naturally-formed SLs on each $F_{1}$ plant were observed after the heading stage to determine whether each $F_{1}$ plant has the Sekiguchi character or not. a) cv. Sekiguchi-himenomochi. b) cv. Sekiguchi-asahi. c) cv. Aichi-asahi. d) cv. Himenomochi. e) Non-glutinous. f) Glutinous.

Sekiguchi-asahi and Sekiguchi-himenomochi) and several normal rice plants were investigated, all $\mathrm{F}_{1}$ plants did not form Sekiguchi lesions. In the case of crosses between cvs. Sekiguchi-asahi and Sekiguchi-himenomochi, however, even $F_{1}$ plants formed Sekiguchi lesions (Table 3).

There was a large difference in size, shape or color of lesions formed by Bipolaris oryzae infection among rice cultivars. Inoculations of normal cultivars (cvs. Asahi and Himenomochi) with $B$. oryzae resulted in typical brown leaf spot lesions. Conversely, progeny of cvs. Sekiguchi-asahi and Sekiguchi-himenomochi produced large Sekiguchi lesions (Plate I-B).

Kiyosawa $^{2)}$ demonstrated that the Sekiguchi lesion on rice cv. Sekiguchi-asahi was conditioned by a single recessive gene, which he designated sl. Our results shown in Tables 2 and 3 suggested that the Sekiguchi lesion formation on cv. Sekiguchi-himenomochi was controlled by a recessive gene, such as $s l$ found in $\mathrm{cv}$. Sekiguchi-asahi.

\section{Literature cited}

1. Isota, J., Kadowaki, Y., Fukuda, M. and Arase, S. (1993). Formation of "Sekiguchi lesion" on rice plant of cv. Himenomochi. Ann. Phytopathol. Soc. Jpn. 59: 295 (Abstr. in Japanese).

2. Kiyosawa, S. (1970). Inheritance of a particular sensitivity of the rice variety, Sekiguchi Asahi, to pathogens and chemicals, and linkage relationship with blast resistance genes. Bull. Nat. Inst. Agric. Sci., Ser. D. 21 : 6172 .

3. Sekiguchi, Y. and Furuta, T. (1965). On a rice mutant showing particular reaction to some spotting disease (Preliminary report). Ann. Phytopathol. Soc. Jpn. 30 : 71-72 (Abstr. in Japanese).

\section{和 文 摘 要}

磯田 淳・門脇義行・荒瀬 栄：イネ品種ヒメノモチに自然発 生した関口病斑

1991 年, 島根県農業試験場水田のイネ品種ヒメノモチに橙黄 色, 大型不整形病斑（関口病斑）を形成する変異株が出現した。 変異株から得た種子 (170 粒) を播種すると， 162 粒 $(95.3 \%)$ が 関口病斑を形成し, 8 粒 $(4.7 \%)$ は形成しなかった。関口病斑形 成 (A 系統)および無形成 (B 系統) イネからの種子をそれぞれ 播種すると，A 系統種子ではそのほとんどすべてが関口病斑を 形成したが，B 系統種子ではその形成の有無がほ汴 $1: 3$ の比率 に分離した。A および B 系統イネのうち関口病斑を形成した個 体から得た種子を播種後, 2,3 イネ品種と交配し, $F_{1}$ 種子の関 口病斑形成の有無を調査した。その結果, 関口病斑形成イネ相互 の交配では調査したすべての個体で関口病斑が形成されたが, その他の正常イネ品種との交配ではまったく形成されなかっ た。以上の結果は, 関口ヒメノモチに発生した関口病斑が関口朝 日同様, 劣性遺伝子により支配されている可能性を示唆した。

(Received September 11, 1995 ; Accepted November 29, 1995) 